9.

\title{
JULIJE MAKANEC KAO DUHOVNI ODGOJITELJ USTAŠKE MLADEŽI
}

\section{Petar Macut}

UDK: 929Makanec, J.:329.18(=163.42)-053.6

Prethodno priopćenje

Sažetak: Uspostavom Nezavisne Države Hrvatske pod paskom Ustaškog pokreta došlo je do cjelokupne reorganizacije društva pod njegovom kontrolom. Posebnu pozornost ustaše su pridavale mladeži, koja je trebala biti odgajana u novoj državi u novom „ustaškom duhu”, „najjasnije" izraženom u ustaškim načelima. U tu svrhu osnovana je posebna organizacija unutar ustaškog pokreta - Ustaška mladež. Julije Makanec (1904.-1945.), filozof i političar, gotovo od samoga početka je bio uključen u rad te organizacije. Krajem 1941. godine imenovan je stožernikom muške ustaške mladeži za Stožer Bilogoru (sjedište u Bjelovaru), da bi već u siječnju 1942. bio promaknut na dužnost odjelnog upravitelja za duhovni odgoj u Upravnom zapovjedništvu Ustaške mladeži u Zagrebu. Reorganizacijom djelovanja Ustaške mladeži koja će se provesti sredinom 1942. Makanec zauzima isti položaj unutar organizacije samo što je naziv odjelnog upravitelja zamijenjen nazivom pročelnika. Svojim intelektualnim radom kao autor niza brošura političko-propagandne provenijencije znatno je utjecao na formiranje svjetonazora članova Ustaške mladeži. Rezultati istraživanja potvrđuju važnost njegove uloge u organizaciji Ustaške mladeži, što je doprinijelo njegovom napredovanju u hijerarhiji Ustaškog pokreta. Na taj način otvaraju se dva do sada neistražena područja historiografije o Nezavisnoj Državi Hrvatskoj: djelovanje Julija Makanca i organizacija Ustaške mladeži.

Ključne riječi: Julije Makanec, Ustaška mladež, ustaška ideologija, Ustaški pokret, odgoj u NDH

\section{Uvod}

ulije Makanec je na marginama povijesnog pamćenja zabilježen kao ministar prosvjete Nezavisne Države Hrvatske koji je svoj životni put završio pred streljačkim vodom 7. lipnja 1945. godine. ${ }^{1}$ Iako je bio visokopozicionirani član Ustaškog pokreta, u očima prevladavajuće paradigme historiografskog istraživanja koja u prvi plan stavlja političke

\footnotetext{
Smrtne presude Vojnog suda Komande zagrebačkog područja 1945., svibanj 12. - 1946., veljača 22., Partizanska $i$ komunistička represija i zločini u Hrvatskoj 1944.-1946. Dokumenti: Zagreb i središnja Hrvatska, (ur. Vladimir GEIGER i dr.), Zagreb 2008., 347. Originalni dokument se nalazi u: HDA, Zagreb, 0870, inv. br. 194. Vrijeme smrti: 7. VI. 1945.; način izvršenja presude: strijeljanje.
} 
odnose moći, Makanec je zaista bio sporedan lik. Međutim, ako iz sfere uže shvaćenog političkog istraživanja skrenemo na probleme ideologije i kulture, Julija Makanca nikako ne možemo zaobići.

Osim toga što je skončao na navedeni način, hrvatska historiografija pretežno veže Makanca samo za još dva događaja: ustanak u Bjelovaru² te novinski napad na Alojzija Stepinca nakon njegove propovijedi na blagdan Krista Kralja 21. listopada 1943. godine. Kao načelnik grada Bjelovara Makanec je imao djelatnoga učešća u tzv. bjelovarskom ustanku. ${ }^{3}$ Taj je ustanak mitologiziran za vrijeme NDH kao najpoznatiji primjer podizanja Hrvata na oružje na Poglavnikov poziv preko radija Velebit. Cini se da će upravo taj događaj biti presudan za uspješan razvoj Makančeve političke karijere ${ }^{4}$ i njegov napredak kroz organizaciju Ustaškog pokreta, iako treba uzeti u obzir njegovu stručnu spremu i angažman u javnom životu između dva rata.

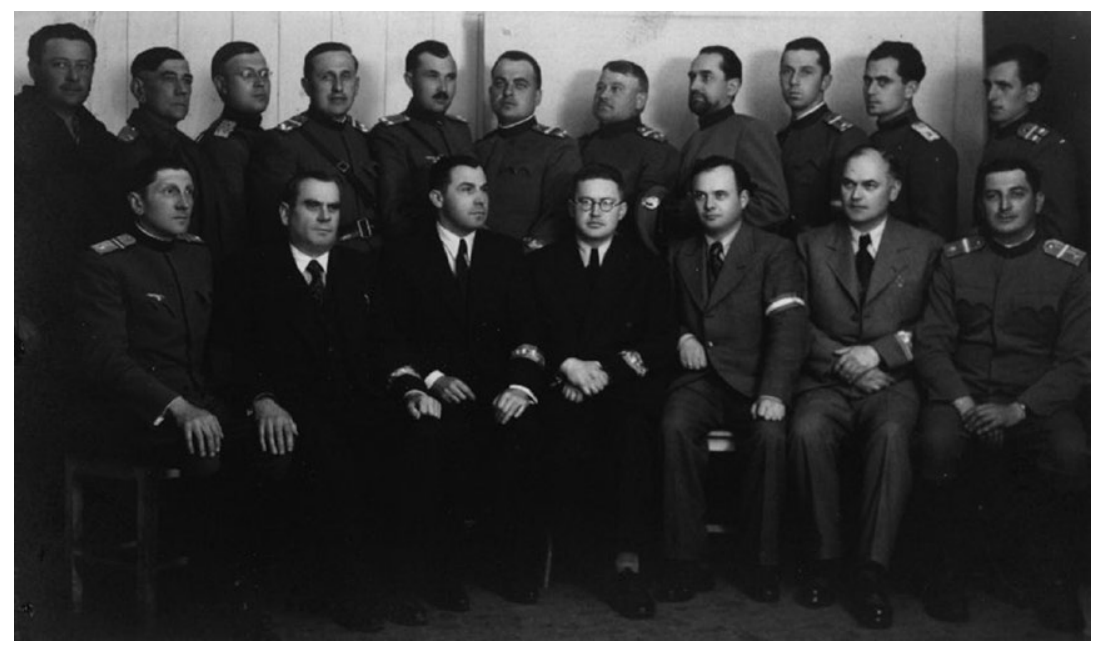

Slika 1. Vođe Bjelovarskog ustanka, 7. travnja 1941. godine, snimljeni 8. travnja 1941. nakon što je dr. Julije Makanec (u sredini, sjedi) proglasio Nezavisnu Državu Hrvatsku s balkona Gradske vijećnice u Bjelovaru

Željko KARAULA, Bjelovarski ustanak: 7.-10. travnja 1941. u povijesnim izvorima: dokumenti, Bjelovar 2012.; Zdravko DIZDAR, „Bjelovarski ustanak od 7. do 10. travnja 1941.”, Casopis za suvremenu povijest, 39/2007., br. 3, 581.-609.

3 Već 15. travnja 1941. u dnevniku Hrvatski narod (god. III., br. 62, str. 4.) u članku pod naslovom Herojska pobuna hrvatske vojske u Bjelovaru kratko je opisan tijek pobune. Također se i u drugom svesku Hrvatske enciklopedije, tiskanoj 1942. godine, pod skupnom natuknicom Bjelovar nalazi bilješka i o bjelovarskom ustanku. Uredništvo je na temelju Makančevog trodijelnog članka iz Hrvatskog naroda opisalo tijek događaja na sljedeći način: „Kad je 6. IV.1941. došlo do rata između Njemačke i bivše Jugoslavije, uskratio je hrvatski narod na poziv Poglavnika dra Ante Pavelića poslušnost jugoslavenskim v[1]astima (sic!). Među mnogobrojnim ustancima osobito se ističe ustanak u Bjelovaru (...).” („Bjelovar”, Hrvatska enciklopedija, sv. 2., Zagreb 1942., 660.) Samo nazivanje tog događaja ustankom već je problematično. Pobuna je puno preciznija riječ.

4 Osim u početku karijere, to sudjelovanje BILO je jedan od glavnih razloga što je Makanec osuđen na smrt. U dispozitivu presude stoji da je kriv: „a) što je kao načelnik u Bjelovaru još za bivše Jugoslavije izdajnički predao u ruke fašističkog neprijatelja razoružavši Jugoslav. vojsku i predavši više stotina oficira i vojnika bivše Jug. vojske okupatoru." (Partizanska i komunistička represija i zločini u Hrvatskoj 1944.-1946., 420.)

5 Do sada najdetaljniji prikaz tog događaja vidjeti u: Jure KRIŠTO, Sukob simbola: politika, vjere i ideologije u Nezavisnoj Državi Hrvatskoj, Zagreb 2001., 92-93. Također i u: ISTI, Katolička crkva i Nezavisna Država Hrvatska 1941.-1945., sv. 1., Zagreb 1998., 113., 115. 
Drugi zabilježeni historiografski moment je napad na zagrebačkog nadbiskupa, objavljen na stranicama Hrvatskog naroda 7. studenoga 1943. u tekstu Pozvani i nepozvani. ${ }^{5}$ Tim člankom Makanec, ne imenujući Stepinca, odgovara na njegovu propovijed osporavajući mu pravo i kompetenciju da se upliće u politička zbivanja. Ostali momenti Makančevog društvenog i političkog života i prije i poslije navedenih događaja u Nezavisnoj Državi Hrvatskoj nisu detaljnije zabilježeni. ${ }^{6}$

Svrha ovoga rada je progovoriti o životu i radu Julija Makanca do ožujka 1943. godine kada je imenovan izvanrednim profesorom filozofije na Mudroslovnom fakultetu u Zagrebu. ${ }^{7}$ U te zamalo dvije godine života i rada Makančeva djelatnost je bitno vezana uz organizaciju Ustaške mladeži u kojoj će on držati jednu od ključnih pozicija. Stoga ćemo se kratko pozabaviti i samom organizacijom Ustaške mladeži, posebno njezinim ustrojem, da bi nam postala jasnija njegova pozicija odjelnog upravitelja za duhovni odgoj. ${ }^{8}$

\section{Djelovanje Julija Makanca od 10. travnja do studenoga 1941. godine}

Uspostava Nezavisne Države Hrvatske zatekla je Makanca na mjestu ravnatelja bjelovarske gimnazije i načelnika grada Bjelovara. ${ }^{9}$ HSS je nakon sporazuma Cvetković-Maček preuzeo vlast i na bjelovarskom području..$^{10}$ Kao član HSS-a Makanec je imenovan načelnikom u studenom 1940. godine. Pripadao je desnoj struji te stranke. Kada je točno položio ustašku prisegu nije utvrđeno, ali se pretpostavlja da je to imao priliku učiniti prilikom posjete Mile Budaka tom gradu početkom 1940. godine. ${ }^{11}$

${ }_{6}$ U leksikonu Tko je tko u NDH?, (ur. Darko Stuparić, Zagreb 1997., 252.-253.) u natuknici o Juliju Makancu pogrešno je navedeno da je imenovan stožernim pobočnikom u Ustaškom stožeru Bilogora 1941. godine. Spomenuto je da od 1942. preuzima dužnost pročelnika za duhovni odgoj Ustaške mladeži te da je u ožujku 1943. imenovan izvanrednim profesorom filozofije na Filozofskom fakultetu u Zagrebu. U listopadu iste godine postaje ministar narodne prosvjete. Osim ove neprecizne faktografije, o njegovom djelovanju u vrijeme NDH nije istraženo - ništa.

Imenovan je temeljem $\$ 114$. Zakonske odredbe o Hrvatskom sveučilištu prema kojem su zakonske odredbe koje se odnose na izbor i stalnost profesora suspendirane na pet godina. U tom razdoblju profesore imenuje Poglavnik, a ostalo nastavno osoblje ministar nastave/prosvjete. Usp. Alma Mater Croatica (dalje: AMC), 4/1941., br. 10, 132. Odredba je donesena 23. listopada 1941. Niti dva tjedna kasnije, 5. studenoga, Zakonska odredba o Hrvatskom sveučilištu je preinačena na način da je Poglavnik dobio pravo imenovati rektora na dvije godine. Osim rektora, Poglavnik je imenovao i dekane. Makanec je imenovan „Odredbom Poglavnika Nezavisne Države Hrvatske od 17. ožujka 1943. (...) izvanrednim profesorom (...) na Mudroslovnom fakultetu Hrvatskog sveučilišta u Zagrebu kod katedre 'Filozofija' za predmete 'Poviest filozofije' i 'Sociologija'.” AMC, 5/1943., br. 10-11, 117.

8 Čini se da su i sami suvremenici bili nesigurni, možda i površni, u utvrđivanju dužnosti pojedinih pripadnika Ustaškog pokreta. Tako upravo vezano za Julija Makanca, u pogovoru njegovoj knjizi eseja Hrvatski vidici (Zagreb 1944.), u bilješci o piscu iz pera Vinka Nikolića stoji da je on imenovan stožernim pobočnikom Ustaškog stožera u Bjelovaru (187.). Kao što ćemo vidjeti, tu je Nikolić zapravo spojio u jednu dvije Makančeve dužnosti koje je obnašao jednu za drugom: bio je logorski pobočnik za grad Bjelovar, a poslije stožernik muške ustaške mladeži za stožer Bilogoru. Tu pogrešku nije primijetio niti Željko Karaula u svom informativnom članku o gradskim načelnicima Bjelovara. Usp. Željko KARAULA, „Gradski načelnici Bjelovara (1871-1945.)”, Cris, 12/2011., br. 1, 214.-215.

9 U siječnju 1940. Makanec je vraćen na mjesto profesora u bjelovarskoj gimnaziji, ubrzo potom imenovan je njezinim ravnateljem, a u studenom iste godine postavljen je za načelnika Bjelovara. Usp. Ž. KARAULA, Gradski načelnici Bjelovara (1871-1945), 214.-215.

10 Usp. Z. DIZDAR, Bjelovarski ustanak od 7. do 10. travnja 1941., 582.

11 Isto, 583. 


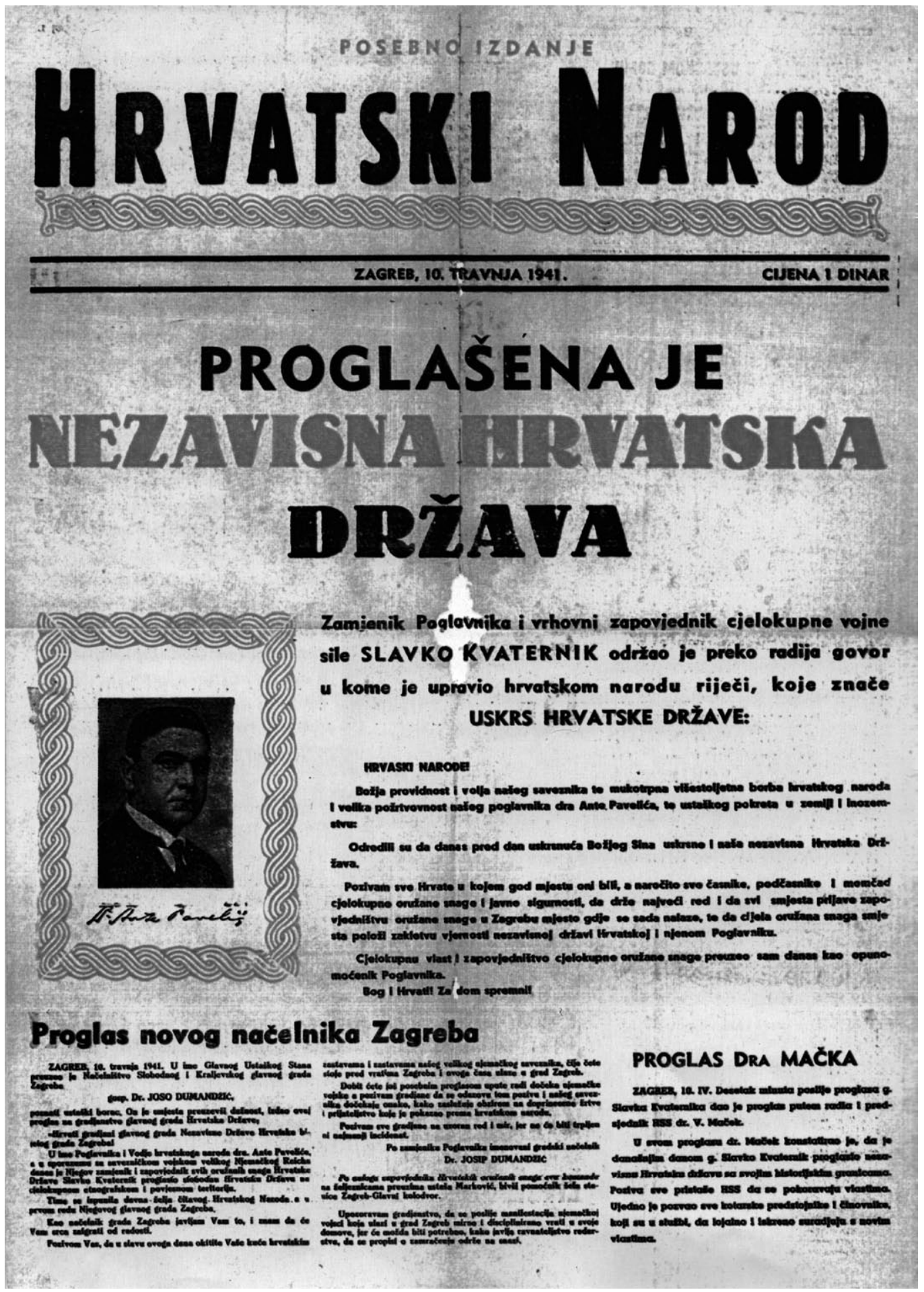

Slika 2. Posebno izdanje Hrvatskog naroda povodom proglašenja Nezavisne Države Hrvatske 10. travnja 1941. 
Za praćenje političke transformacije Julija Makanca od pripadnika desnog krila HSS-a u ustašu od presudne važnosti su njegovi tekstovi koje je objavljivao u novopokrenutom bjelovarskom tjedniku Nezavisna Hrvatska. ${ }^{12}$ Već od prvoga broja kroz taj list možemo pratiti Makančeve protokolarne dužnosti kao načelnika Bjelovara ${ }^{13}$ kao i njegovo napredovanje kroz hijerarhiju Ustaškog pokreta. Taj napredak dogodio se tek nakon što je Makanec ideološki evoluirao od riječi:

Hrvatski narod u svojoj ljubavi prema miru i u svojoj dubokoj čovječnosti ni danas ne želi ništa tuđe, on i danas ne želi da svoju sreću zida na trajnom poniženju i trajnoj nesreći bilo $\operatorname{koga}(\ldots)^{14}$

iz travnja 1941. godine do zloslutnog upozorenja iz studenog iste godine:

Neka znade svaki, da trutova i sebičnjaka, da društvenih parazita Hrvatska ne treba i da ce ih iskorieniti. ${ }^{15}$

Svoje konačno „da” režimu Makanec je izrekao u svibnju 1941. Na toj liniji je ostao sve do svibnja 1945. bez ikakvog znaka kolebanja. U već spomenutom prvom broju Nezavisne Hrvatske, na čijoj naslovnici Makančev tekst govori o „ljubavi prema miru”, na trećoj stranici u rubrici domaćih vijesti saznajemo da je

Ustaški pokret, koji je u slobodnoj i nezavisnoj državi Hrvatskoj preuzeo vlast, počeo s čišćenjem nepoželjnih elemenata (...) Kod reorganizacije Gradskog redarstva odpušteni su iz gradske službe svi Srbi redari (...) Ova ispražnjena mjesta popunit će se ispravnim $\mathrm{Hr}$ vatima $(. . .)^{16}$

Otpuštanje svih Srba iz službe zasigurno se poklopilo s tadašnjim mišljenjem onih građana hrvatske nacionalnosti koji su podržavali proglašenje Nezavisne Države Hrvatske o nadzastupljenosti Srba u redarstvenim i žandarmerijskim postajama. Tada se to povezivalo $s$ često okrutnim i nečovječnim postupanjima prema žiteljima ne samo tog kraja u Kraljevini Jugoslaviji. Ipak, gubitak radnih mjesta nije bio događaj koji bi natjerao na razmišljanje i doveo u pitanje novouspostavljenu vlast. Međutim, okrutni pokolj žitelja srpske nacionalnosti bjelovarskog kraja koji se dogodio nedaleko od Gudovca 28. travnja $1941 .{ }^{17}$ upravo je događaj koji je od svih koji su mogli objektivno biti upoznati s njim zahtijevao opredjeljenje. Da je Makanec odlučio ignorirati taj zločin te se staviti u službu pokreta govori nam već sljedeći njegov tekst Ustaška načela, također s naslovnice Nezavisne Hrvatske. ${ }^{18} \mathrm{Za}$ njih Makanec kaže:

Ta načela znače organsku sintezu osnovnih vrijednosti hrvatske stranke prava i hrvatske seljačke stranke i čine tako čvrsti i nerazorivi temelj naše narodne budućnosti. ${ }^{19}$

\footnotetext{
Urednik Ivan Šestak, god. 1, br. 1 (19. travnja 1941.) - god 2, br. 65 (29. kolovoza 1942.); nastavlja se kao Bilogora. Npr. usp. „Proslava rođendana vođe njemačkog Reicha”, Nezavisna Hrvatska (dalje NH), br. 2, 26. 4. 1941., 2.

Julije MAKANEC, „Hrvatska država”, NH, br.1, 19. 4. 1941., 1.

Julije MAKANEC, „Misao 'Pomoći”’, NH, br. 33, 29. 11. 1941., 1.

„Reorganizacija gradskog redarstva”, $N H$, br. 1, 19. 4. 1941., 3.

17 Više o tom pokolju vidjeti u: Željko KARAULA, „Slučaj Gudovac' 28. travnja 1941.”, Radovi Zavoda za hrvatsku povijest, 39/2007., 197.-208.

18 Julije MAKANEC, „Ustaška načela”, $N H$, br. 4, 10. 5. 1941., 1.

19 Isto. Opširnije tumačenje ustaških načela Makanec će objaviti u priručniku državno-narodne nastave pod naslovom Politička nastava, Zagreb, 1943., 53.-68.
} 
Položivši test odanosti Makanec je 21. svibnja 1941. na dan Poglavnikovog „poviestnog govora” na Markovom trgu u kojem je objasnio čin potpisivanja Rimskih ugovora, imenovan logorskim pobočnikom u Bjelovaru. ${ }^{20}$ To je bila njegova prva dužnost u Ustaškom pokretu.

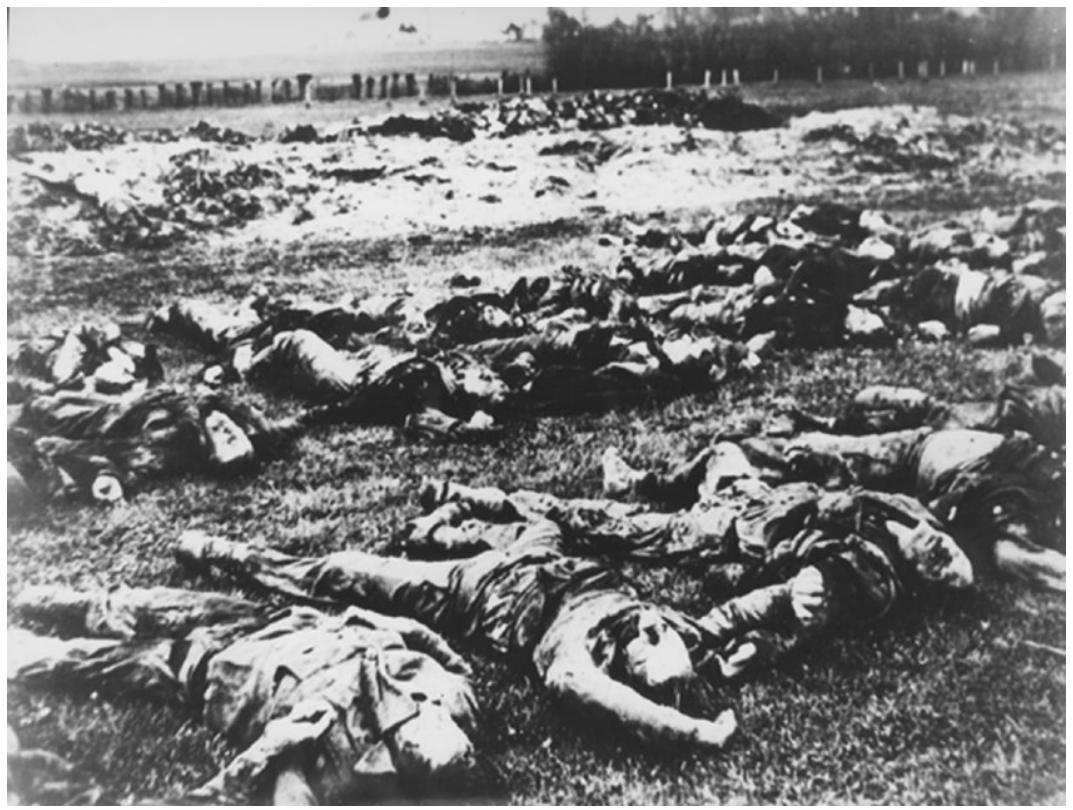

Slika 3. Ekshumirane žrtve pokolja u Gudovcu kod Bjelovara 28./29. travnja 1941.

Samo nekoliko dana kasnije, 25. svibnja, po prvi put nastupa Makanec kao logorski pobočnik i drži govor na velikoj političkoj tribini koja se simultano tih dana održavala na cijelom teritoriju NDH nad kojim se prostirala efektivna ustaška vlast. Tom tribinom bilo je potrebno objasniti narodu zašto je dio Dalmacije ustupljen Talijanima. Ne ulazeći u ocjenu samoga čina i sadržaja Rimskih ugovora, ipak je potrebno istaknuti osobni kompromis koji je i u ovom slučaju podnio sam Makanec. Naime, tumačeći ustaška načela u već spomenutom tekstu napisanom prije potpisivanja Rimskih ugovora, zapisao je i ove riječi:

Kao što je god živom organizmu potrebno raspolagati svim svojim organima, tako je i $\mathrm{Hr}$ vatskoj državi potrebno raspolagati svim svojim historijskim pokrajinama (...). ${ }^{21}$

Dva tjedna kasnije pravdao je gubitak Dalmacije govoreći:

Naša vjera u bu[du]ćnost hrvatskog naroda pod vodstvom Poglavnika je neslomiva i srušit će sve zapreke, koje naiđe na svom putu! ${ }^{22}$

20 „Glavni Ustaški Stan u Zagrebu od 21. svibnja 1941. donio je sljedeću odredbu: U smislu točke 4. ustaškog Ustava, Glavni Ustaški Stan na prijedlog dosadašnjeg ustaškog povjerenika (Mije Hansa, op. P. M.), a po odredbi Poglavnika, ovim imenuje (...) Logornim pobočnicima: Ustaše Dra Julija Makanca (...)”, NH, br. 6, 24. 5. 1941., 4. Također vidjeti: Stožernici, Logornici i Tabornici, Ustaša - vijesnik hrvatskog ustaškog oslobodilačkog pokreta (dalje USTAŠA), 11/1941., br.1, 15.

${ }_{21}$ Julije MAKANEC, „Ustaška načela”, $N H$, br. 4, 10. 5. 1941., 1.

22 „Hrvatska je narodna duša progovorila”, $N H$, br. 7, 31. 5. 1941., 2. 
Svoje jasno i nedvosmisleno pristajanje uz teoriju i praksu ustaškog pokreta Julije Makanec je nastavio tumačeći knjigu Ante Pavelića Strahote zabluda ${ }^{23}$ natpisom Poglavnik o komunizmu. ${ }^{24}$ Kao što ćemo vidjeti kasnije, to Poglavnikovo djelo, uz nezaobilazna ustaška načela, postalo je trajan izvor inspiracije mnogih njegovih propagandno-ideoloških tekstova namijenjenih pripadnicima Ustaške mladeži.

\section{1. Stožernik za mušku mladež stožera Bilogora}

Deset dana nakon Makančevog prvog govora kao ustaškog dužnosnika došlo je do administrativnog preustroja Nezavisne Države Hrvatske. Dana 4. lipnja 1941. godine osnivaju se velike župe. Teritorijalnu podjelu na 22 velike župe i grad Zagreb u istom rangu te gradove i sela pratila je administrativna podjela Ustaškog pokreta na stožere, logore i tabore, na čijem čelu su bili stožernici, logornici i tabornici. Osim paralelizma između administrativne podjele države i ustaškog pokreta, postojao je paralelizam i unutar ustaškog pokreta između političkih i vojnih činova. Činovi u političkoj organizaciji Ustaškog pokreta imali su svoje vojne ekvivalente $s$ jednakim pravima. Na taj način je ideal vojničkog ustroja prenošen i na političke dužnosti. Tako je npr. Makancu kao logorskom pobočniku pripadao status dočasnika u „usporedbi s činom i pravima ustaškog vodnika”. ${ }^{25}$ Čin časnika u političkoj organizaciji Ustaškog pokreta „u usporedbi s činom i pravima poručnika”26 pripast će mu imenovanjem na mjesto stožernika za mušku mladež stožera Bilogora u studenom. U kolovozu je smijenjen $s$ mjesta bjelovarskog načelnika ${ }^{27}$ zadržavši mjesto ravnatelja bjelovarske gimnazije. To će mjesto zadržati i kao stožernik za mušku ustašku mladež.

Zadaću da organizira rad cjelokupnog stožera mladeži shvatio je vrlo ozbiljno, iako se na toj poziciji zadržao samo dva mjeseca prije sljedećeg promaknuća. Svjedočanstvo o svojoj djelatnosti djelomično je zapisao u svom izvještaju Rad Ustaške mladeži u Bjelovaru u studenom i prosincu. ${ }^{28}$ Osim intenzivnih nastupa Ustaške uzdanice i Ustaškog junaka na kazališnim priredbama, s članovima Starčevićeve mladeži održavat će "(se) tjedno jedanput sastanci, na kojima će se čitati i tumačiti Poglavnikovo djelo 'Strahote zabluda". ${ }^{29}$ Prve skice tog predavanja, kao što je već rečeno, već je objavio u tekstu Poglavnik o komunizmu. Navedenom temom bavit će se Makanec još jednom na stranicama Nezavisne Hrvatske i to će biti njegov posljednji autorski rad u tom bjelovarskom tjedniku. ${ }^{30}$

Politički svjetonazor koji je Makanec kao ustaški dužnosnik prihvatio do svibnja 1941. zadržat će neizmijenjen sve do kraja rata. Tom uvjerenju žrtvovat će sve svoje intelektualne pa i moralne snage, prilagođavajući svoja prijeratna stajališta onima koja je od njega zahtijevala „duhovna situacija vremena”. Najjasnije će se to vidjeti u njegovom djelovanju kao pročelnika za duhovni odgoj Ustaške mladeži.

\footnotetext{
Ante PAVELIĆ, Strahote zabluda, Zagreb 1941.

Julije MAKANEC, „Poglavnik o komunizmu”, NH, br. 25, 4. 10. 1941., 3.

„Odredba o činovima u Ustaškom pokretu”, $N H$, br. 15, 26. 7. 1941., 3.

Isto.

Usp. Ž. KARAULA, Gradski načelnici Bjelovara (1871-1945.), 216.

NH, br. 37, 3. 1. 1942., 4.

Isto.

30 Radi se o tekstu „Komunizam i seljaštvo”, $N H$, br. 39, 17. 1. 1942., 1.-2. Članak će kasnije biti pretiskan u listu Ustaška mladež, 2/1942., br. 21.
} 


\section{Administrativni ustroj organizacije Ustaške mladeži}

Ante Pavelić, osnivač i vođa Ustaškog pokreta, nije od početka bio siguran na koji način organizirati Ustašku mladež. Prve naznake rješavanja problema ustroja mladeži u Ustaškom pokretu nalazimo već u svibnju osnivanjem zapovjedništva za vojnu prednaobrazbu kao i radnu službu mladosti. ${ }^{31}$ Krajem lipnja Poglavnik donosi Odredbu o sastavu Ustaškog pokre$t a^{32}$ koji se dijeli na tri grane: političko-organizacijsku, Ustašku vojnicu te Ustašku nadzornu službu. Briga o mladeži pripala je grani političke organizacije pokreta. „Posebno polje rada jest organiziranje i odgoj ustaškog Podmladka unutar Ustaškog pokreta, koji će biti svrstan u postrojbe." ${ }^{3}$ Iz ovako nedefinirane odredbe jasno se vidi da konačna odluka o načinu ustroja mladeži još nije donesena. Taj problem riješen je Zakonskom odredbom o osnivanju Ustaške mladeži od 12. srpnja 1941. godine. ${ }^{34}$ Cjelokupna mladež svrstana je u četiri dobne skupine podijeljene po spolovima. Ustaška uzdanica okupljala je djecu od 7 do 11 godina. Ustaški junaci su bili djeca od 11 do 15 godina. Ustaška Starčevićanska mladež obuhvaćala je mladež od 15 do 18 godina. Mladež na fakultetima su sačinjavali svi sveučilišstarci i sveučilištarke, koji su već ranije organizirani u posebnom stožeru. ${ }^{35}$

Prema toj prvotnoj zamisli izloženoj u Zakonskoj odredbi na čelu pojedinih grana djelovanja Ustaške mladeži bili su odjelni upravitelji za: vojničku prednaobrazbu, duhovni odgoj, promidžbu, umijeće, tjelovježbu, zdravstvo, društveno-gospodarsku brigu te kućanstvo (samo za žensku mladež). U točci 7. te iste odredbe propisano je da će teritorijalni ustroj Ustaške mladeži pratiti granice župa, gradova i sela te će na njihovom čelu biti postavljeni stožernici, logornici i tabornici, posve jednako kao i kod organiziranja odraslih članova pokreta. Kada se Zakonska odredba o djelovanju Ustaške mladeži u studenom 1941. pojavi u Dužnostni$k u,{ }^{36}$ doći će do izmjene dobne granice unutar Starčevićeve mladeži. Dobna granica od tada je obuhvaćala sve mladiće i djevojke od 15. do 21. godine života.

U kolovozu 1942. izlazi Propisnik o zadaći, ustrojstvu, radu i smjernicama 'Ustaše' - Hrvatskog oslobodilačkog pokreta kojim se ponovno modificira dobna podjela Ustaške mladeži. Mjesto sveučilišne mladeži (sveučilišna mladež organizirana je u posebnom stožeru koji obuhvaća sveučilište, bez teritorijalne pripadnosti) zauzimaju Ustaški jurišnici bez definirane dobne granice, ali uz pretpostavku punoljetnosti. Ustaški jurišnici potpadaju pod vojne vlasti (usp. $\$ 71$. toč. 4.). Mijenja se i ustroj po odjelima te pod pročelništvo za duhovni odgoj spadaju odjel za ideološku izgradnju, odjel za umijeće te odjel za promidžbu (usp. \$71. toč. 7.).

U prosincu 1942. pročelništvo za duhovni odgoj izdalo je Pravilnik o radu pročelništva za duhovni odgoj i odjelnih upraviteljstava za ideoložku izgradnju, za umieće i za promičbu. ${ }^{37} \mathrm{U}$ njemu se detaljno opisuje opseg kompetencija kao i ciljevi odgoja Ustaške mladeži. Od na-

\footnotetext{
31 „\$1. Cjelokupna muška mladost, koja nije uposlena ma u kojoj grani privredne djelatnosti, od navršene 15 . godine do navršene 18. godine i cjelokupna sveučilišna mladost vršit će pod nadzorom ministarstva domobranstva vojničku prednaobrazbu i rad u radnim jedinicama u trajanju od četiri mjeseca.” („Zakonska odredba o vojničkoj prednaobrazbi i radnoj službi mladosti (5. svibnja 1941.)”, Hrvatski Glas (Zagreb), br. 79, 6. 5. 1941., 3.) Desetak dana poslije Pavelić Odredbom o nadopuni ustava 'Ustašé', 3. točci II. dijela dodaje uredbu prema kojoj se sva sveučilišna omladina svrstava u poseban Sveučilišni stožer. Usp. Hrvatski Glas, br. 87, 15. 5. 1941., 3.

32 „Iz ustaškog pokreta. Odredba o sastavu Ustaškog pokreta”, USTAŠA, 11/1941., br. 3, 16.

33 „Osnovana je 'Ustaška mladež”, Hrvatska straža, br. 26, 29. 6. 1941., 7.

34 „Zakonska odredba o osnivanju Ustaške mladeži”, USTAŠA, 11/1941., br. 4, 11.

35 Vidi bilj. 25.

36 „Zakonska odredba o djelovanju Ustaške mladeži”, Dužnostnik, 1/1942., br.1, 45.

37 Dužnostnik, 1/1942., br.10, 612.-615.
} 
vedena tri odjela, najvažnijim će se pokazati odjel za ideološku izgradnju. Zadaća tog odjela opisana je u $\$ 4$. Pravilnika:

Zadaća je odjela za ideoložku izgradnju, da pruža i razpoređuje građu, kojom se u pripadnicima Ustaške mladeži, budi i izgrađuje hrvatska nacionalna-politička sviest i ustaški nazor o svietu. $^{38}$

Budući da je Julije Makanec kao pročelnik bio izravno odgovoran i pretpostavljen navedenim odjelima, njegov intelektualni rad i pozicija moći unutar Ustaške mladeži omogućit će mu da u sferi odgoja izvrši utjecaj, posebno u dijelu ideološke izgradnje.

\section{Ideološka izgradnja Ustaške mladeži}

Tjednik Nezavisna Hrvatska od 31. siječnja 1942. obavještava svoje čitatelje da je

Dr. Julije Makanec, ravnatelj bjelovarske gimnazije i stožernik Ustaške mladeži stožera Bilo Gora Imenovan (sic!) (...) odjelnim upraviteljem za duhovni odgoj u Upravnom zapovjedništvu Ustaške mladeži u Zagrebu, te je već nastupio na svoju dužnost. ${ }^{39}$

Na tom mjestu zamijenio je Grgu Pejnovića. ${ }^{40}$

Dolaskom Julija Makanca u Zagreb, Ustaška mladež poprima obrise ozbiljne organizacije. Već u ožujku 1942. godine pokreće se Dužnostnik - službeni list Ustaške mladež $i^{41}$ koji će izlaziti jednom mjesečno. Intenzivira se i izdavačka djelatnost, posebno tiskanje propagandnih brošura, od kojih će upravo Makančeve biti najkvalitetnije i najbrojnije. Osim toga, kao odjelni upravitelj, a kasnije pročelnik za duhovni odgoj Ustaške mladeži, upravo će on određivati što će i kako cjelokupna Ustaška mladež čitati i na koji način tumačiti pročitano. A u tim smjernicama kao obavezna djela naći će se sve ono što on bude osobno napisao - svaka njegova pojedina knjiga i brošura bit će propisana kao obvezno štivo pri poučavanju pripadnika mladeži.

To je službeno propisano u $\$$ 6. pravilnika o radu pročelništva za duhovni odgoj gdje se navode sredstva rada odjela za ideološku izgradnju: izdavanje knjiga i brošura, uputa za tumačenje knjiga i izdanja te preporuka izdanja za taborske knjižnice. ${ }^{42} \mathrm{U}$ svakom od tih sredstava rada Makanec će imati presudnu ulogu.

\section{1. Knjige i brošure Julija Makanca pisane za Ustašku mladež}

Ovdje se nećemo baviti izdavaštvom Ustaške mladeži općenito jer je vrlo raznovrsno i bogato te zahtjeva monografsku obradu. U toj raznovrsnosti ističu se radovi Julija Makan-

Isto, 613 .

$39 \quad N H$, br.41, 31. 1. 1942., 4.

40 USTA ̌́ A, 11/1942., br. 4, 10.

41 Dužnostnik je nastao spajanjem četiri lista: Ustaške uzdanice, Ustaškog junaka, Ustaške Starčevićeve mladeži te glasila ženske ustaške mladeži Ustaška dužnostnica. Usp. Zdenka TURČINEC, „Izdavači/nakladnici u Nezavisnoj Državi Hrvatskoj", Časopis za suvremenu povijest, 32/2000,. br.1, 65.

42 Usp. Dužnostnik, 1/1942., br.10, 613. 
ca. On je kao autor apsolutni rekorder po broju tiskanih brošura i knjiga u nešto više od godinu dana koliko je zapravo bio na mjestu odjelnog upravitelja odnosno pročelnika za duhovni odgoj Ustaške mladeži.

Intenzitet kojim je u Bjelovaru pisao prigodničarske tekstove, u Zagrebu je zamijenio izdavanjem brošura i knjiga. Tako se ubrzo po njegovom dolasku u Upravno zapovjedništvo Ustaške mladeži tiska u nakladi Promičbe Ustaške mladeži brošura Poglavnik o boljševizmu. ${ }^{43}$ U toj brošuri Makanec sva poglavlja knjige koju prikazuje sažima i navodi pod jednakim naslovima kako ih je autor poslagao u knjizi tiskanoj 1941. godine. ${ }^{44}$ Prema svom sadržaju Makančeva brošura je tek skripta od četrdeset stranica namijenjena lakšem usvajanju gradiva. Niti ne trudeći se u taj tekst ugraditi dio svog znanja, Makanec nekritički preuzima i sažima sadržaj koji ima pred sobom u Pavelićevoj knjizi. Govori o „semitima-iztočnjacima”, „inorodnim nametnicima”, „satanskim boljševističkim tipovima”, „Židovima intelektualcima”, boljševičkoj zarazi kojima se suprotstavljaju „izkonske obranbene snage”, „zdravi evropski narodi", o mudroj i pronicavoj odluci Adolfa Hitlera da napadne prije nego li sam bude napadnut te o općem hrvatskom narodnom ustanku pod Poglavnikovim vodstvom.

Da bi lakše objasnio veličinu Poglavnikova duha i djela koje je ostvario uspostavom Nezavisne Države Hrvatske, Makanec tiska brošuru Ustaške vrline. ${ }^{45}$ Iako bismo se mogli složiti s definicijom vrline koju nam predlaže autor („Pod vrlinom razumijevamo sposobnost čovjeka, da se opre zlu i da učini ono, što je pravedno i pošteno"»46), već na sljedećoj stranici čini etički salto mortale konstatacijom da

(...) svaka zajednica uzima pravo da istrijebi, uništi ili bar učini neškodljivima one pojedince, koji je radi posve posvemašnjeg nedostatka vrlina slabe i upropaštavaju. ${ }^{47}$

Opće postulate kršćanske etike miješa s postulatima nacističkog svjetonazora koji je implementiran na hrvatsku političku scenu njemačkom vojnom prisutnošću. Prihvaćanjem političke uloge članice Nove Europe ${ }^{48}$ koja u svojim temeljima ima hegemoniju nad onima koje ta ideologija smatra inferiornima, etika za Julija Makanca postaje tek retorička figura. Da je tome tako, vjerojatno je bio svjestan i sam Makanec. Inače ne bi mogao pisati da biti religiozan čovjek znači izvršavati što nam nalaže savjest jer je savjest glas Božji ${ }^{49}$ usporedno $s$ konstatacijom da postoje vrijedni i bezvrijedni članovi ljudske zajednice. ${ }^{50}$ Kada se tako proturječne konstatacije spoje u jednu cjelinu, jasno je zbog čega se inzistira na slijepoj poslušnosti kao najvažnijoj vrlini u sustavu ustaških vrlina. ${ }^{51}$

\footnotetext{
Julije MAKANEC, Poglavnik o boljševizmu, Zagreb 1942., 40.

Usp. Ante PAVELIĆ, Strahote zabluda, Zagreb 1941.

Julije MAKANEC, Ustaške vrline, Zagreb 1942., 39.

Isto, 3.

Isto, 4 .

48 „Neprijatelji žele prikazati Njemačku zemljom terora i tiranije, zemljom, gdje se intelektualci i predstavnici kulture osuđeni na poniženje i muke. Koliko je to daleko od istine!” („Budućnost Hrvatske u ovoj Europi”, NH, br. 36, 24. 12. 1941., 1 .

49 Usp. J. MAKANEC, Ustaške vrline, 7.

50 Isto, 19.

51 „Dogadjaji su pokazali, da je on (Ante Pavelić, op. P. M.) uvijeka tačno i nepogrješivo ocjenjivao prilike i donosio odluke, koje su za hrvatski narod bile korise i spasonosne. S obzirom na te činjenice svaki ustaša mora imati neograničeno povjerenje u Poglavnika i njegovu državničku mudrost, te to mora i svojim držanjem u svakoj prilici pokazati.” (Isto, 14.) Sličnu misao nalazimo izraženu i u ovim riječima: „U hrvatskoj državi duh podpunog reda i rada može zavladati samo po mladeži - po ustaškoj mladeži - čiji je osnov odgoja stega i poslušnost.” („Ustaška mladež pokoljenje nove Hrvatske”, Dužnostnik, 1/1942., br. 2, 50.)
} 
U brošuri Veliko raskršśe ${ }^{52}$ Makanec ukratko prikazuje živote putove i politička nastojanja Ante Starčevića, Stjepana Radića, Milana Šufflaya te Ante Pavelića. U toj kratkoj brošuri Makanec samo ponavlja na više mjesta ponovljena stajališta da je uloga Ante Starčevića bila u tome da probudi bìlo hrvatskoga naroda te da ga upozori na opasnost od jugoslavenske ideologije ilirskog pokreta. Stjepan Radić je za Starčevićevu ideju hrvatske države pridobio široke slojeve hrvatskog seljaštva te je svoj uspjeh platio glavom:

Njegovo nasljedstvo primio je u najtežim trenutcima hrvatske povijesti Poglavnik koji je nauku Ante Starčevića sjedinio s naukom Stjepana Radića u skladu cjelinu izraženu u ustaškim načelima $(. . .)^{53}$

Uvođenje diktature bio je impuls Poglavniku, smatra Makanec, da se odluči za emigraciju. Prije negoli je krenuo, osnovao je 7. siječnja 1929. Ustaški pokret, što je bila svjesna i namjerna mistifikacija samoga Ante Pavelića. Njegova politička djelatnost u emigraciji proklamirala je kao svoj cilj ispunjenje vjekovnog hrvatskog sna - samostalne države.

Promičba ustaške mladeži izdala je i knjigu Julija Makanca Velična i propast kraljevstva hrvatskoga. ${ }^{54} \mathrm{U}$ toj knjizi Makanec na jednostavan, gotovo trivijalan način progovara o nekim važnijim datumima hrvatske povijesti Srednjega vijeka. Događaji iz rane hrvatske povijesti su izabrani na način da potiču stereotipe koje je ustaška ideologija brižljivo njegovala. Tako se ističe da Slaveni, kao narod, u sebi nemaju državotvornog nagona te se stoga opravdava inzistiranje na tzv. gotskoj ili iransko-kavkaskoj teoriji o porijeklu Hrvata budući da su Slaveni u nacističkoj ideologiji inferiorni: „Mi Hrvati nismo čisti Slaveni, što dokazuje već naš jaki državotvorni nagon (...)" ${ }^{55}$ Osim državotvornog nagona, Hrvati su, prema Makančevoj kratkoj povijesti, uvijek bili okrenuti zapadnom svijetu te su uvijek držali do svoje zadane riječi. Opis ratovanja kneza Domagoja pod Barijem Makanec je iskoristio da upozori da je već tada „hrvatska bojna sila” nastupala u „obrani Europe od vaneuropskih sila”. ${ }^{66}$ To je posve u skladu $s$ opetovanom propagandom rata protiv najezde $s$ Istoka u kojem je djelatnog učešća imala i NDH preko svojih dobrovoljačkih postrojbi. Osim toga, u tekstu možemo naći i takve besmislice da su Hrvati bili svjesni svoje samobitnosti već u 10. stoljeću. ${ }^{57}$ Održavana su predavanja Hrvatska za vrijeme kraljeva Ustaškim Junacima i Starčevićevoj ustaškoj mladeži. ${ }^{58}$

\section{2. Upute za tumačenje knjiga i izdanja}

$\mathrm{U} \$ 1$. Pravilnika o radu pročelništva za duhovni odgoj ${ }^{59}$ stoji da su njegove temeljne zadaće u tome da određuje smjernice, da potiče te osigurava i raspoređuje tekstove i potrebne instrumente za odgoj "poviestne i državne sviesti” svih članova Ustaške mladežii. ${ }^{60}$ Zada-

\footnotetext{
Julije MAKANEC, Veliko raskršcé, Zagreb 1942., 45.

Isto, 6.-7.

Julije MAKANEC, Veličina i propast kraljevstva hrvatskoga, Zagreb 1943., 86.

35 Isto, 15. Malo dalje čitamo: „(...) svoj državotvorni nagon i svoju vojničku sposobnost (dugujemo) gotskoj i iranskokavkaskoj komponenti svoga narodnog bića." (Isto, 15.-16.)

$56 \quad$ Isto, 37.

Isto, 43.

58 Dužnostnik, 1/1942., br.1, 10. i 13.

59 Puni naslov toga pravilnika glasi: Pravilnik o radu pročelništva za duhovni odgoj i odjelnih upraviteljstava za ideoložku izgradnju, za umieće $i$ za promičbu.

60 Dužnostnik, 1/1942., br.10, 612.
} 
tak određivanja smjernica Makanec je ispunjavao ne samo pišući brošure u kojima tumači temeljne zadatke i ciljeve ustaškog pokreta, njegovu ideologiju i nastojanja, već je nizom tekstova objavljenih u Dužnostniku usmjeravao i ostale dužnosnike Ustaške mladeži diljem $\mathrm{NDH}$ na koji će način, kojim slijedom i ritmom poučavati mlade pripadnike Ustaškog pokreta. On je stoga ne samo duhovni odgojitelj Ustaške mladeži, već i instruktor onima koji su se hijerarhijski nalazili u domeni njegovog utjecaja.

Da bismo dobili približan uvid u utjecaj Julija Makanca na formaciju i recepciju ustaške ideologije među ustaškom mlađom inteligencijom općenito, a na Ustašku mladež posebno, navest ćemo primjer recepcije njegovog teksta o Anti Starčeviću i Stjepanu Radiću, tiskanog u Dužnostniku 1944. godine s prethodnom napomenom uredništva: „Kako bismo vam olakšali rad za izpit II. stupnja do izlaska priručnika navađamo Vam gradivo, koje morate obraditi s Junacima kroz mjesec dana." ${ }^{\prime 61}$ Zanimljivo je da autor pod tim tekstom uopće nije potpisan, iako je sasvim jasno da se radi o Makančevu tekstu. Osim u ovom službenom časopisu Ustaške mladeži, navedeno „ispitno gradivo” tiskano je i u Priručniku državno-narodne nastave, ${ }^{62} \mathrm{u}$ brošuri Veliko razkrš́cé, ${ }^{63} \mathrm{u}$ knjizi Entwicklung des kroatischen Nationalismus, ${ }^{64} \mathrm{u}$ tjedniku Spremnost, ${ }^{65} \mathrm{u}$ Prosvjetnom životu ${ }^{66} \mathrm{u}$ knjizi Hrvatski vidici. ${ }^{67}$ Osim ovih tekstova, navedenih kao primjer, i mnogi drugi njegovi radovi pojavljuju se pretiskivani i po nekoliko puta u različitim ustaškim publikacijama. Osim o njegovom utjecaju, ta nam činjenica govori i o tome da je ustaškom pokretu nedostajao veći broj potkovanih intelektualaca koji bi mogli autentično tumačiti pojedine aspekte ustaške ideologije. ${ }^{68}$ Makanec nam se pokazuje u tom smislu kao jedan od vodećih i utjecajnijih.

U drugom broju Dužnostnika odjelni upravitelj za duhovni odgoj daje nalog svim stožerima da na temelju priloženog predavanja rastumače ustaškoj mladeži najznačajnije misli dr. Milana Šufflaya. Priloženo predavanje tiskano je u istom broju časopisa, a iako nepotpisano znademo da se radi o Makančevu tekstu o tom značajnom hrvatskom intelektualcu. Na nekoliko stranica Makanec je cjelokupno Šufflayevo djelo sveo na nekolicinu momenata prema potrebi ustaške ideologije i odgoja mladeži u tom duhu. Ustvrdio je da je Šufflay prvi jasno i nedvojbeno istakao važnost i sudbonosnost granice na Drini koja u ustaškoj ideologiji označava granicu Istoka i Zapada. Budući da su Hrvati oduvijek branili tu granicu, logično je, prema Šufflayu, da ih se nazove i braniteljima zapadne kulture. Hrvati su štitili Europu od najezde s Istoka. U to vrijeme (travanj 1942.) još je bila u jeku ofenziva na SSSR, a bitka na tom bojištu u vojnom smislu nije bila odlučena.

61 Dužnostnik, 3/1944., br.1-3, 5.

${ }^{62}$ Julije MAKANEC, Politička nastava. Priručnik državno-narodne nastave. Svezak I., Zagreb 1943., 30.-40. Na str. 2. stoji sljedeća napomena državnog vođe rada: „Ovaj priručnik jedini je mjerodavan za vođe DRS (državna radna služba, op. P. M.) kod provođenja državno-narodne nastave u postrojbama DRS, a prema naučnoj osnovi državnonarodne nastave i osnovi za njezinu provedbu (ON br. 245. od 25. siečnja 1943). Priručnik služi samo za unutarnju upotrebu DRS, te se ne može u druge svrhe upotriebiti.” Dopis je datiran 27. ožujka 1943.

63 J. MAKANEC, Veliko raskršće, 8.-27.

64 Julijus MAKANEC, Entwicklung des kroatischen Nationalismus, Zagreb 1944., 17.-60. Radi se o luksuzno uređenom prijevodu Makančeve brošure Veliko razkršće.

65 Pod naslovom Nacionalizam Stjepana Radića Makanec je sažeo najbitnije točke ranijega teksta. Usp. „Nacionalizam Stjepana Radića”, Spremnost, 1/1942., br. 25, 16. 8. 1942., 2.

66 „Nacionalizam Stjepana Radića”, Prosvjetni život, 1/1942., 204.-206.

67 Julije MAKANEC, Hrvatski vidici. Nacionalno-politički eseji, Zagreb 1944., 38.-55.

68 Poznata je stvar, kaže Makanec, „da nama za sada još ne dostaje dovoljan broj spremnih i pogodnih ljudi na svim položajima pa ih nedostaje i ovdje”. Usp. Julije MAKANEC, „Smjernice za rad odjelnih upravitelja za duhovni odgoj”, Dužnostnik, 1/1942., br. 2, 99. 
Drugi moment koji Makanec želi rastumačiti pripadnicima Ustaške mladeži bavi se pojmom čovječnosti kod Šufflaya. Makanec taj pojam tumači ovako:

Čovječnost - taj izraz u ustima Ustaše Milana Šufflaya ne znači nipošto neodlučnost i mlohavost u obrani vlastitih prava i vlastite egzistencije. ${ }^{69}$

U nastavku razmatranja autor zaključuje da se borba za egzistenciju nikada ne smije izroditi u bestijalnost. ${ }^{70}$ Ali da je ono samo dekor govori već zaključak toga odlomka:

A da se ovdje ne radi samo o teoretskim razmatranjima, autor uvjerava da takovu (čovječnu, op. P. M.) Hrvatsku Poglavnik s uspjehom svakoga dana sve to više ostvaruje. ${ }^{71}$

U ožujku 1942. godine Makanec izdaje i smjernice za rad odjelnim upraviteljima za duhovni odgoj. Svoju i ulogu ostalih duhovnih odgojitelja Makanec vidi ovako:

Dok je zadaća odjelnih upravitelja za promičbu, da se pobrinu, da se izdanja Ustaške mladeži kao i knjige i brošure preporučene po Zapovjedničtvu što više među pripadnicima Ustačke mladeži šire, zadaća je odjelnih upravitelja za duhovni odgoj, da se pobrinu da svi oni duševni i idejni sadržaji, što se u tim izdanjima nalaze, zaista prodru u dušu i misao onih, kojima su namijenjeni. ${ }^{72}$

Osim „praćenja literature”, duhovni odgajatelji moraju imati razvijeni osjećaj za ono što je prikladno i značajno za pravilan duhovni razvoj Ustaške mladeži. Posebno se, još jedanput, inzistira da se Starčevićevoj mladeži preporuči čitanje i tumačenje Poglavnikova djela Strahote zabluda. ${ }^{73}$ Kao ustaški dužnosnik u Bjelovaru on je već čitao i tumačio to djelo Starčevićevoj ustaškoj mladeži, a sada to „preporuča” s pozicije moći svim organizacijama Ustaške mladeži u Nezavisnoj Državi Hrvatskoj.

U studenom i prosincu 1942. Makanec je zapovjedio voditeljima sastanaka Ustaške mladeži da se kroz ta dva mjeseca ima „čitati i tumačiti” djelo Ivana Oršanića O pokretu i vođi pokreta na temelju priloženog razmatranja kojemu je autor sam Makanec. ${ }^{74}$ I tu se ponavljaju već poznate formulacije o „vjekovnim narodnim idealima”, o „istini pokreta” i „,nepogrešivosti vođe”. Princip vođe dominira i u ovom razmatranju kao temeljna ideološka os:

Vođa u sebi nosi vjekovne ideale naroda, ne donosi ništa, što nije čvrsto usidreno u stvarnosti narodne duše. ${ }^{75}$

69 Dužnostnik, 1/1942., br. 2, 53.

70 Možda je na umu imao upravo pokolj u Gudovcu u koji je kao načelnik Bjelovara bio upućen.

71 Dužnostnik, 1/1942., br. 2, 53.

72 Dužnostnik, 1/1942., br.1, 98.

73 Makanec je kao stožernik za mušku ustašku mladež stožera Bilogora na svoju vlastitu inicijativu uveo čitanje i tumačenje toga djela pripadnicima Starčevićeve ustaške mladeži. Usp. Julije MAKANEC, „Rad Ustaške mladeži u Bjelovaru u studenom i prosincu”, $N H$, br. 37, 3. 1. 1942., 4.: „Za starije članove djačkoga ogranka Starčevićeve mladeži održavat će se tjedno jedamput sastanci, na kojima će se čitati i tumačiti Poglavnikovo djelo 'Strahote zabluda'. Ove sastanke vodi stožernik (Makanec, op. P. M.).”

74 Usp. Dužnostnik, 1/1942., br.10, 630.-631. Razmatranje se nalazi na 631.-638. Taj tekst tiskan je u u Hrvatskoj Smotri. Usp. 10/1942., br. 10, 569.-577.

75 Isto, 633. Zanimljivo je ovdje napomenuti da je o ovom problemu progovorio i Stjepan Zimmermann. U tekstu objavljenom u Spremnosti Zimmermann upravo kritizira navodno osluškivanje bila naroda. Žalac Zimmermannove kritike ublažio je sam urednik Spremnosti Ivo Bogdan falsifikatom Zimmermannovog teksta u koji je ubacio odlomak koji glorificira ulogu Ante Pavelića. Više o tom problemu vidjeti u: Petar MACUT, „Zimmermannova kritika režima Ante Pavelića - uzroci i posljedice", Intelektualci i rat. Zbornik radova s Desničinih susreta 2011., (ur. Drago Roksandić i Ivana Cvijović Javorina), Zagreb 2012., 167.-182. 
Posljednju Makančevu okružnicu u smislu rasporeda sadržaja predavanja Ustaškoj mladeži nalazimo u ožujku 1943., samo dva tjedna prije nego li će biti imenovan izvanrednim profesorom na Mudroslovnom fakultetu u Zagrebu. Okružnica se bavi rasporedom građe predavanja za Starčevićevu ustašku mladež za cijelu 1943. godinu. Za prvi dio godine, do travnja, obavezno je čitanje i tumačenje djela Danijela Crljena Ustaška načela. ${ }^{76}$ Poslije toga „će prieči na proučavanje Poglavnikova djela Poglavnik o boljševizmu koju je izdalo Zapovjedničtvo Ustaške mladeži." Taj zadatak trebaju ispuniti do listopada. A nakon toga, u studenom i prosincu 1943. godine, Starčevićeva ustaška mladež proučavat će „razpravu prof. Ivana Oršanića: O pokretu i vođi pokreta". ${ }^{77}$ Jednostavnom usporedbom s nalogom od prošle godine koji je identičan ovome iz 1943. dolazimo do uzorka nečega što bismo mogli nazvati kurikulumom odgoja Ustaške mladeži.$^{78} \mathrm{O}$ tome je svakako potrebno detaljnije progovoriti na drugome mjestu.

\section{$\cos$ \\ Julije Makanec as a SPiritual eduCATOR of THE USTASHE YOUTH}

The Ustashe movement emerged in a time of great political instability, in emigration. The organization functioned on paper, but it turned out to be very ineffective. After the Independent state of Croatia (Nezavisna Država Hrvatska - NDH) was established in April 1941, the Ustashe movement and its leader Ante Pavelić became its legislature, its judiciary and its executive, with the opportunity to shape the society in the way they saw fit. However, lack of experience, a failure to implement general principles of the Ustashe movement in practice, and a permanent state of war meant that the way they ran the country was marked by constant improvisation, accompanied by ceaseless restructuring of the movement itself. The Ustashe Youth was not immune to these problems, either. Formally, it was founded on May 17th 1941, but it suffered from serious organizational problems, understaffing and a lack of ideas. Still, it could be argued that in spite of these unfavourable circumstances, its formation was approached with a lot of idealism and passion. Julije Makanec, a high ranked member of the organization, contributed with his organizing skills and literary prowess to spreading the ideological influence of the Ustashe movement in all regions where the regime exerted power. Also influential was the prolific publishing activity of the Youth's propaganda departmet (Promičba Ustaške mladeži) which published, among other things, all of Makanec's propaganda works intended for the spiritual formation of the youth. In those works, Makanec explained, instructed, taught, incited and spread the ideology of the Ustashe movement. As an intellectual of wide-ranging interests that he was before the war, Makanec was often forced to compromise and make sacrifices, but he considered them a necessary in achieving the worthy goal that was Croatian independence. He proved to be the ideal person for the position of the section manager in charge for spiritual formation at the Ustashe Youth Command and was very successful. His propaganda works, which aspired to be read as theoretical textbooks, explaining the

\footnotetext{
76 Iako taj tekst nije tiskan kao posebna brošura, u knjizi Politička nastava, tiskanoj za potrebe radne službe, nalazimo i Makančeva tumačenja ustaških načela. Usp. J. MAKANEC, Politička nastava, 53--68.

77 Dužnostnik, 2/1943., br. 3, 27.

78 Usp. Dužnosntik, 1/1942., br.10, 630.-631.
} 
principles of the movement's ideology in a simple and entertaining way represent the peak in quality of such production in NDH. For this reason, Julije Makanec is regarded as one of the leading spiritual educators of the Ustashe youth.

Keywords: Julije Makanec, the Ustashe youth, Ustashe movement, Ustashe ideology, education in the Independent State of Croatia

\section{$\cos$}

\section{Izvori i literatura}

Novine i časopisi

Alma Mater Croatica 1941.

Dužnostnik 1942.-1944.

Hrvatski Glas 1941.

Nova Hrvatska 1941.

Ustaša 1941.

\section{Knjige, brošure i članci}

Zdravko DIZDAR, „Bjelovarski ustanak od 7. do 10. travnja 1941.”, Časopis za suvremenu povijest, 39/2007., br. 3, 581.-609.

Slavko GOLDSTEIN, 1941. godina koja se vraća, Zagreb 2007.

Željko KARAULA, Bjelovarski ustanak: 7.-10. travnja 1941. u povijesnim izvorima: dokumenti, Bjelovar 2012.

Željko KARAULA, „Gradski načelnici Bjelovara (1871-1945.)”, Cris, 12/2011., br. 1, 214.-215.

Željko KARAULA, „Slučaj Gudovac' 28. travnja 1941.”, Radovi Zavoda za hrvatsku povijest, 39/2007., br.1, 197.-208.

Jure KRIŠTO, Katolička crkva i Nezavisna Država Hrvatska 1941.-1945., Zagreb 1998.

Jure KRIŠTO, Sukob simbola: politika, vjere i ideologije u Nezavisnoj Državi Hrvatskoj, Zagreb 2001.

Julije MAKANEC, Poglavnik o boljševizmu, Zagreb 1942.

Julije MAKANEC, Politička nastava. Priručnik državno-narodne nastave. Svezak I., Zagreb 1943.

Julije MAKANEC, Ustaške vrline, Zagreb 1942.

Julije MAKANEC, Veličina i propast kraljevstva hrvatskoga, Zagreb 1943.

Julije MAKANEC, Veliko raskršće, Zagreb 1942.

Julijus MAKANEC, Entwicklung des kroatischen Nationalismus, Zagreb 1944.

Ante PAVELIĆ, Strahote zabluda, Zagreb 1941.

Partizanska i komunistička represija i zločini u Hrvatskoj 1944.-1946. Dokumenti: Zagreb i središnja Hrvatska, (ur. Vladimir GEIGER i dr.), Zagreb 2008.

Zdenka TURČINEC, „Izdavači/nakladnici u Nezavisnoj Državi Hrvatskoj”, Časopis za suvremenu povijest, 32/2000,. br.1, 51.-71. 